\title{
JAN ŁOPUSKI
}

\author{
Uniwersytet Mikołaja Kopernika w Toruniu
}

\section{EUROPEIZACJA PRAWA DOTYCZĄCEGO UMOWY UBEZPIECZENIA}

I. Tematem konferencji jest stan europeizacji polskiego prawa ubezpieczeń gospodarczych. Jest to dosyć szeroki i ciekawy temat; chciałbym więc na wstępie wyjaśnić, jak ja go rozumiałem przygotowując moje wystąpienie. Zaproszenie na konferencję mówi o stanie europeizacji naszego prawa ubezpieczeniowego; oznacza to, że mamy na uwadze pewien proces i rozważamy etap jaki ten proces osiągnął. Ma to być proces europeizacji. Ale co konkretnie rozumiemy przez europeizację naszego prawa ubezpieczeniowego? Przecież Polska byla, jest i pozostanie krajem europejskim, a więc prawo jej - również ubezpieczeniowe - jest prawem europejskim. Spróbowałem sięgnąć myślą 70 lat wstecz. Polska nie miała wtedy jednolitego prawa ubezpieczeniowego. Na jej poszczególnych obszarach obowiązywały przepisy niemieckiej ustawy ubezpieczeniowej z 1908 r., austriackiej ustawy z 1917 r. i rozporządzenia P. R. z 1928 r. o tymczasowych przepisach o umowie ubezpieczenia. Czy można bylo wtedy mówić o potrzebie europeizacji polskiego prawa ubezpieczeniowego? Z pewnością nie, bo to było przecież prawo europejskie, które wymagało tylko ujednolicenia. Dlaczego więc po 70 latach mówimy o potrzebie europeizacji naszego prawa ubezpieczeniowego? Dlatego, że przez 45 lat po zakończeniu II wojny światowej nasze prawo ubezpieczeniowe, pod presją natury politycznej, było dostosowywane do innego modelu stosunków ubez- 
pieczeniowych niż prawo ubezpieczeniowe państw Zachodniej Europy mających utrwalony ustrój demokratyczny, gospodarkę rynkową i wysoki poziom cywilizacyjnego rozwoju. Tymczasem w Polsce Ludowej istniał państwowy monopol ubezpieczeniowy, a samo ubezpieczenie było jednym z instrumentów społecznej i gospodarczej polityki państwa. Europeizacja naszego prawa ubezpieczeniowego powinna więc polegać na odcięciu się od dziedzictwa prawa ubezpieczeniowego z okresu PRL, a w każdym razie tych jego rozwiązań i koncepcji, które odpowiadały ówczesnemu ukladowi stosunków. A to jest nielatwe zadanie. Dziedzictwo to pozostawiło bowiem trwałe ślady nie tylko w treści przepisów - również aktualnie obowiązujących - ale także w naszej społecznej świadomości. Wielu osobom z trudem przychodzi oderwanie się od przeszłości.

II. Europeizacja prawa dotyczącego umowy ubezpieczenia jest zagadnieniem, które nie może ograniczać się do dostosowania nasze go prawa do wspólnotowego prawa europejskiego. Prawo to jest nadal bardzo powściągliwe w regulowaniu cywilnoprawnego stosunku ubezpieczenia. Reguluje wprawdzie w niewielkim zakresie zawieranie umów ubezpieczenia, natomiast nie reguluje samej treści stosunku ubezpieczenia, pozostawiając to prawu właściwemu dla umowy ubezpieczenia. Mówiąc o europeizacji naszego prawa dotyczącego umowy ubezpieczenia mam więc na myśli jego zbliżenie do prawa innych państw europejskich. Stopień tego zbliżenia mógłby wskazywać na stan europeizacji naszego prawa ubezpieczeniowego w omawianym zakresie.

III. O ile dostosowanie naszego prawa ubezpieczeniowego do dyrektyw europejskich jest koniecznością, to zbliżenie naszego prawa regulujące go umowę ubezpieczenia do prawa innych państw europejskich taką koniecznością nie jest. Prawo ich nie jest zresztą jednolite. Jeżeli chodzi o prawo państw mających rozwinięte systemy prawa ubezpieczeniowego, a nas interesujących ze względu na powiązania gospodarcze, a mianowicie Anglii, Francji i Niemiec, to Anglia nie ma, jak dotąd, skodyfikowanego prawa o umowie ubezpieczenia ( $z$ wyjątkiem ubezpieczenia morskiego), Francja ma sto- 
sunkowo nowoczesne skodyfikowane prawo ubezpieczeniowe z 1976 r., a w Niemczech nadal obowiązuje ustawa o umowie ubezpieczenia z 1908 r. Jednak istnieją pewne ogólne zasady, które w prawie ubezpieczeniowym tych państw są respektowane, co w stosunkach międzynarodowych ułatwia wzajemne zrozumienie i wspólpracę. Chodzi więc o zbadanie w jakim zakresie nasze prawo o umowie ubezpieczenia zbliża się do tych zasad wspólnych prawu państw, które osiągnęły wysoki stopień cywilizacyjnego rozwoju; pozwoli to na określenie stanu europeizacji naszego prawa ubezpieczeniowego.

IV. Jeżeli chodzi o uregulowanie umowy ubezpieczenia w przepisach księgi trzeciej, tytułu XXVII k.c., to chciałbym zwrócić uwagę na następujące zagadnienia: 1/ swobody kontraktowej, 2/ ogólnych warunków ubezpieczenia, 3/ umów konsumenckich, 4/ granic ubezpieczalności.

1/ Swoboda kontraktowa. Również po ostatniej nowelizacji przepisów kodeksu cywilnego o umowie ubezpieczenia przepis art. 807 $\$ 1$ k.c. pozostaje bez zmian. Przepisy tytułu XXVII obowiązują bezwzględnie, chyba że przewidują wyjątki. Jest to więc ograniczenie swobody kontraktowej stron zawierających umowę ubezpieczenia, niespotykane w angielskim prawie ubezpieczeniowym, a w prawie francuskim stosowane w różnym zakresie (art. L. 111-2 „Code des assurances"). Niemiecka ustawa z 1908 r. przewiduje ograniczenia swobody kontraktowej, które nie mają jednak zastosowania do niektórych ubezpieczeń związanych z obrotem gospodarczym ( $\$ 187$ ). W kodeksie cywilnym w brzmieniu z 1964 r. tego rodzaju ograniczenie swobody kontraktowej nie miało w znacznej części zastosowania do umów ubezpieczenia zawieranych przez jednostki gospodarki uspołecznionej, co miało pewną logikę. Natomiast dodany przez ostatnią nowelizację art. 807 \$ 2 k.c. stanowi, że w ubezpieczeniach dotyczacych obrotu z zagranicą mogą być stosowane warunki ubezpieczeń odbiegające od przepisów tytułu XXVII. Ten przepis wprowadzający odrębne reżimy prawne dla umów ubezpieczenia zawieranych w obrocie wewnętrznym i zagranicznym jest 
oczywistą spuścizną myślenia rodem z PRL, kiedy obrót wewnętrzny, socjalistyczny, poddany planowi gospodarczemu był przeciwstawiany obrotowi $\mathrm{z}$ zagranica, poddanemu działaniu praw rynkowych. Jakie jest uzasadnienie, aby ubezpieczenie związane z obrotem gospodarczym (np. transportowe) traktować inaczej, jeżeli chodzi o swobodę kontraktową, w zależności od tego, czy chodzi o obrót wewnętrzny czy zagraniczny? A co to znaczy ubezpieczenie dotyczące obrotu z zagranicą? Czy pojęcie to obejmuje umowę ubezpieczenia zawartą między podmiotami polskimi (mającymi w Polsce siedzibę lub zamieszkanie), ale dotyczącą przedmiotu znajdującego się za granicą lub odpowiedzialności, którą ubezpieczający może ponosić w działalności zagranicznej? A czy obrót ubezpieczeniowy wewnątrz UE ma być traktowany jako obrót z zagranicą? Uważam przepis art. $807, \S 2$ k.c. za stwarzający wątpliwości interpretacyjne $\mathrm{i}$ trudny do pogodzenia $\mathrm{z}$ dążeniem do europeizacji prawa o umowie ubezpieczenia. Nie mówiąc już o tym, że inne przepisy kodeksu cywilnego dotyczące zobowiązań z umów nie wprowadzają różnic w regulowaniu stosunków w zależności od tego, czy są związane z obrotem wewnętrznym czy zagranicznym.

Natomiast uważam, że przepis art. $807 \S 2$ k.c. brzmiałby bardziej sensownie, gdyby mówil o ubezpieczeniach dotyczących nie „obrotu z zagranicą”, ale „obrotu gospodarczego”. Ograniczenia swobody kontraktowej mające na celu ochronę ubezpieczającego przed wykorzystywaniem przez ubezpieczyciela jego silniejszej pozycji może być uzasadnione w ubezpieczeniach, które określiłbym jako ubezpieczenia dla ludności. Inny jest bowiem społeczny aspekt ubezpieczenia mającego zapewnić spokojną egzystencję osoby fizycznej, często niezorientowanej w zawiłościach prawa ubezpieczeniowe go, czy nie rozumiejącej warunków ubezpieczenia, niż ochrony ubezpieczeniowej związanej z działalnością gospodarczą, w której ochrona ubezpieczeniowa może przecież stanowić element transakcji handlowych. Należy ponadto założyć, że podmiot prowadzący działalność gospodarczą jest zorientowany jakiej ochrony ubezpieczeniowej potrzebuje i na jakich warunkach. Jeżeli sam nie jest dostatecznie zorientowany, to może skorzystać z pomocy do- 
radcy lub pośrednika ubezpieczeniowego. W ubezpieczeniach związanych z obrotem gospodarczym ograniczenia swobody kontraktowej stron nie mają zatem uzasadnienia.

2/ Ogólne warunki ubezpieczenia. Nowy art. 812 § 2 k.c. zawierający ustawowe uregulowanie treści ogólnych warunków ubezpieczenia wydaje mi się być całkowicie zbyteczny, zwłaszcza że są to przepisy instrukcyjne (\$6). Porównywane przeze mnie ustawodawstwa ubezpieczeniowe państw Zachodniej Europy nie regulują treści ogólnych warunków ubezpieczenia, natomiast regulują treść polisy, jako podstawowego dokumentu ubezpieczeniowego. Zamiast ustawowego regulowania treści ogólnych warunków ubezpieczenia bardziej racjonalnym rozwiązaniem byłoby opracowanie przez organizacje ubezpieczeniowe wzorcowych ogólnych warunków zalecanych towarzystwom ubezpieczeniowym, które byłyby stosowane powszechnie, jak to jest w Niemczech czy państwach skandynawskich. Przy w miarę elastycznym ustawowym uregulowaniu umowy ubezpieczenia wzorcowe ogólne warunki ubezpieczenia w praktyce zastępują uregulowanie ustawowe, podlegają okresowym rewizjom i stanowią przedmiot komentarzy.

3/ Umowy konsumenckie. Przykładem nieuwzględnienia różnic w spolecznych i gospodarczych aspektach ubezpieczeń dla ludności i ubezpieczeń związanych z obrotem gospodarczym jest obowiązujący od 1 stycznia 2004 r. art. 384 § 5 k.c.) Zgodnie jego treścią każdą umowę ubezpieczenia, niezależnie od tego czy zawartą z osobą fizyczną czy prawną, a w przypadku osoby fizycznej niezależnie od tego czy związaną z jej działalnością gospodarczą lub zawodową czy nie, należy traktować jako umowę konsumencką, a zatem podlegająca odpowiednim przepisom kodeksu cywilnego o zobowiązaniach umownych. Tymczasem zarówno art. $22^{1}$ k.c. jak i dyrektywy europejskie ograniczają pojęcie konsumenta do osoby fizycznej. Umowy ubezpieczenia w obrocie gospodarczym są często poprzedzane negocjacjami, najczęściej również z powołaniem się na jakieś wzorcowe warunki. Należy więc założyć, że tak zawarta umowa ubezpieczenia odpowiada woli stron mających pełną 
świadomość co do treści zawieranej umowy. Umowy ubezpieczenia zawierane w obrocie gospodarczym nie mają zatem podstawowych cech umów zawieranych $z$ konsumentami, a więc osobami potrzebującymi szczególnej ochrony wynikającej z przepisów art. 384-385 k.c., a stosowanie ich do tych umów stanowi istotne ograniczenie swobody kontraktowej, gdyż może prowadzić do podważania ważności postanowień zawartych umów. Wszelkie ograniczenia swobody kontraktowej w ubezpieczeniach związanych z obrotem gospodarczym są trudne do pogodzenia $z$ dążeniem do europeizacji polskiego prawa ubezpieczeniowego.

4/ Granice ubezpieczalności. Dotyczący tego zagadnienia art. 827 \$1-2 k.c. wymaga zasadniczej rewizji. Jako zasadę podstawową należy przyjąć, że ubezpieczenie nie obejmuje szkody spowodowanej winą umyślną ubezpieczającego, a odmienne postanowienie umowy ubezpieczenia byłoby dotknięte nieważnością (por. art. L. 113-1 francuskiego „Code des assurances”). Należy bowiem przyjąć, że mamy w tym przypadku do czynienia ze zdarzeniem pozbawionym elementu losowości. Natomiast ubezpieczenie może obejmować następstwa zdarzeń spowodowanych z winy, również umyślnej, osób, za które ubezpieczający odpowiada cywilnie, gdyż w tym przypadku element losowości bez wątpienia występuje. Czy ustawowe wyłączenie odpowiedzialności ubezpieczyciela powinno obejmować również rażące niedbalstwo ubezpieczające go jest kwestią dyskusyjną - jednak gdyby tego rodzaju wyłączenie miało być wprowadzone, to odpowiedni przepis nie powinien być obowiązujący bezwzględnie. W przeciwieństwie do umyślności rażące niedbalstwo ubezpieczającego zawiera bowiem element losowości. W prawie porównawczym brak jest w tej sprawie jednolitości. W prawie angielskim „wilful misconduct” ubezpieczającego (a jest to szczególna postać niedbalstwa wysokiego stopnia) wyłącza odpowiedzialność ubezpieczyciela, co nie wyklucza objęcia jej umową. Uzależnienie zapłaty odszkodowania od „zasad współżycia społecznego albo interesów gospodarki narodowej" (art. 827 \$1 in fine) w sposób całkowicie zbyteczny wprowadza element niepewno- 
ści w stosowaniu prawa. Klauzula „zasad współżycia społecznego” ma w systemie prawa cywilnego pozycję nadrzędną, a więc zbyteczne jest jej powołanie w tym przepisie, natomiast powołanie się na interes gospodarki narodowej jest oczywistym reliktem $\mathrm{z}$ okresu PRL, wprowadzającym nierówność w traktowaniu stron.

V. Rozważając uregulowanie ubezpieczeń obowiązkowych w ustawie $z$ dnia 22 maja 2003 r. i innych przepisach, dotyczących w szczególności ubezpieczeń odpowiedzialności zawodowej, pod kątem widzenia europeizacji polskiego prawa ubezpieczeniowe go należy uwzględnić następujące zagadnienia:

1/ wprowadzenie odrębnej kategorii prawnej ubezpieczeń obowiązkowych, będących wprawdzie ubezpieczeniami powstającymi na podstawie umowy, ale podlegających ogólnym przepisom odmiennym od przepisów regulujących ubezpieczenia zawierane dobrowolnie,

2/ zakres ubezpieczeń obowiązkowych,

3/ objęcie ubezpieczeniem obowiązkowym odpowiedzialności powstałej z własnej, umyślnej winy ubezpieczającego.

Ad 1/ Prawo państw zachodnio-europejskich, w szczególności jeżeli chodzi o trzy systemy brane przeze mnie pod uwagę, jest zdecydowanie niechętne wprowadzaniu ubezpieczeń obowiązkowych bez szczególnego uzasadnienia społecznego. W szerszym zakresie wprowadza takie ubezpieczenie prawo francuskie, a mianowicie w odniesieniu do ubezpieczenia odpowiedzialności cywilnej z tytułu: użytkowania pojazdów mechanicznych i użytkowania kolei linowych, a także odpowiedzialności myśliwych i osób prowadzących prace budowlane. Każde z tych ubezpieczeń regulowane jest odrębnie. W żadnym z porównywanych przeze mnie systemów prawa ubezpieczeniowego nie wprowadza się odrębnej, ogólnej kategorii prawnej ubezpieczenia obowiązkowego podlegającego szczególnemu reżimowi prawnemu. Jeżeli ważny interes społeczny tego wymaga ustawodawca wprowadza obowiązek za- 
warcia umowy ubezpieczenia, określając wymagania, jakie umowa taka powinna spełniać.

Natomiast ustawa z 22 maja 2003 r. wprowadza odrębną kategorię prawną ubezpieczenia obowiązkowego i zawiera stosunkowo obszerne przepisy dotyczące wszystkich ubezpieczeń obowiązkowych, regulujące stosunek z umowy ubezpieczenia obowiązkowego w sposób szczególny.

Ad 2/ Jeżeli chodzi o zakres ubezpieczeń obowiązkowych dotyczących mienia to ustawa o ubezpieczeniach obowiązkowych wprowadza tylko ubezpieczenie obowiązkowe budynków rolnych (art. 59-77). Kwestia celowości wprowadzenia takiego ubezpieczenia obowiązkowego była niejednokrotnie dyskutowana, również w pracach parlamentarnych w latach 1989-1990, gdy przystępowano do reformowania naszego prawa ubezpieczeniowego. Koronnym argumentem za jego utrzymaniem była niska świadomość polskiego chłopa dotyczącą potrzeby takiego ubezpieczenia. Należy się zastanowić, czy w przededniu naszego wejścia do UE jest nadal dopuszczalne posługiwanie się takim argumentem. Można przypomnieć, jak kiedy w czasie wielkiej powodzi w 1997 roku rolnicy, których ziemiopłody uległy zniszczeniu, zaczęli zwracać się o pomoc finansową do państwa. Ówczesny premier p. Cimoszewicz, zapytał się ich wtedy dlaczego nie byli ubezpieczeni. Było to jak najbardziej słuszne postawienie sprawy, chociaż politycznie przeciwko premierowi wykorzystane. Nie ma żadnego uzasadnienia, aby państwo wyręczało rolnika w myśleniu o jego interesach i potrzebie korzystania z ochrony ubezpieczeniowej mienia będącego jego własnością, niezależnie od tego, czy chodzi o budynki, inwentarz czy ziemiopłody.

W odniesieniu do ubezpieczenia odpowiedzialności cywilnej niekwestionowane jest społeczne znaczenie ubezpieczenia OC posiadaczy pojazdów mechanicznych. Jest to też jedyne obowiązkowe ubezpieczenie przewidziane i szczególowo uregulowane w dyrektywach europejskich. W odniesieniu do wprowadzania innych ubezpieczeń obowiązkowych prawo wspólnotowe pozostawia swobodę państwom członkowskim. 
W ostatnim okresie, a zwlaszcza w 2003 roku, wprowadzono w Polsce kilkadziesiąt obowiązkowych ubezpieczeń odpowiedzialności cywilnej wynikającej $\mathrm{z}$ wykonywania określonego zawodu. Ubezpieczenie odpowiedzialności zawodowej - ryzyko to określane jest w angielskiej terminologii jako ,moral hazard”, rozumiane jako ryzyko zaniedbania - jest w państwach europejskich stosowane powszechnie, jednak bez stosowania przymusu. Nieznane mi są przesłanki tej nagłej zmiany w świadomości jaka u nas nastąpiła, a dotyczącej spolecznego znaczenia ubezpieczenia odpowiedzialności zawodowej, która mogłaby uzasadniać tego rodzaju rozszerzenie obowiązku ubezpieczenia tej odpowiedzialności. Czyżby brak zaufania do świadomości i poczucia odpowiedzialności osób wykonujących te zawody? A może to też dziedzictwo z okresu PRL - społeczeństwa biernego, wykonującego posłusznie nakazy władzy państwowej, która myśli za obywateli i zapewnia im ochronę, oczywiście na koszt tegoż społeczeństwa.

Ad 3/ Artykuł 9.2 ustawy o ubezpieczeniach obowiązkowych stanowi, iż umowa obowiązkowego ubezpieczenia odpowiedzialności cywilnej obejmuje szkody wyrządzone również umyślnie przez samego ubezpieczającego. Przepis ten jest sprzeczny z podstawową zasadą prawa ubezpieczeniowego państw Zachodniej Europy, a w każdym razie porównywanym przeze mnie prawem angielskim, francuskim i niemieckim. Jest bowiem sprzeczny z samą istotą ubezpieczenia, o czym już wspomniałem. Zgodnie ze stanowiskiem miarodajnej doktryny francuskiej ustawowy zakaz ubezpieczenia następstw umyślnego postępowania samego ubezpieczającego jest uzasadniony względami porządku publicznego i moralności. Natomiast w umowach międzynarodowych wprowadzających obowiązkowe ubezpieczenie odpowiedzialności, stosowana jest zasada przyjęta w angielskim prawie ubezpieczeniowym, zgodnie z którą ubezpieczenie takie nie obejmuje szkód spowodowanych przez ubezpieczającego umyślnie, a także przez jego winę nieumyślną szczególnie wysokiego stopnia („wilful misconduct"). 
Nie do przyjęcia jest argument uzasadniający ten kuriozalny przepis, a mianowicie, że ubezpieczyciel, który wyplacił poszkodowanemu odszkodowanie za szkodę spowodowaną z winy umyślnej ubezpieczającego może od niego dochodzić zwrotu wypłaconego odszkodowania. Ubezpieczający, który umyślnie wyrządza szkodę na osobie lub w mieniu osobie trzeciej popełnia przestępstwo ścigane $z$ urzędu, a więc szanse uzyskania od niego zwrotu odszkodowania mogą być znikome; natomiast przepis taki otwiera drogę do nadużyć ubezpieczeniowych. Trudny do przyjęcia jest również argument, że wspomniany przepis zapewnia ochronę poszkodowanym. Ubezpieczenie jest dzialalnością gospodarczą, a nie spoleczną czy charytatywną. Argument ochrony poszkodowanych nie może uzasadniać przepisu sprzecznego z zasadą, którą określitbym jako zasadę doktrynalną prawa ubezpieczeniowego, mającą uzasadnienie natury moralnej. Odwolywanie się do podobnych przepisów socjalistycznego prawa ubezpieczeniowego, kiedyś stosowanego przez państwowe zakłady ubezpieczeń jest mało przekonywujące.

VI. I wreszcie uwaga natury ogólnej. Jeżeli mamy europeizować nasze prawo ubezpieczeniowe, co miałoby ułatwiać naszym zagranicznym partnerom w stosunkach ubezpieczeniowych zaznajomienie się z treścią tego prawa i jego zrozumienie, to należałoby je odpowiednio usystematyzować. A tymczasem postulat uregulowania prawa ubezpieczeniowego według podstawowej systematyki przyjętej w nauce prawa był od początku prac nad reformowaniem prawa ubezpieczeniowego pomijany. W ustawie o działalności ubezpieczeniowej pozostają skumulowane przepisy dotyczące umowy ubezpieczenia, kolizyjne, jurysdykcyjne, dotyczące struktur organizacyjnych towarzystw ubezpieczeniowych, nadzoru nad ubezpieczeniami, organizacji ubezpieczeniowych, które w systematycznym układzie prawa ubezpieczeniowego wymagałyby odpowiedniego wyodrębnienia. Umowa ubezpieczenia dobrowolnego ma pozostać uregulowana w kodeksie cywilnym, a umowa ubezpieczenia obowiązkowego w odrębnej ustawie, chociaż dotyczą tej samej materii. $\mathrm{Z}$ czysto legislacyjnego punktu widzenia reformowanie naszego 
prawa ubezpieczeniowego określiłbym jako kompletną amatorszczyznę. A przecież wspólczesny francuski kodeks ubezpieczeń, abstrahując od merytorycznej treści jego przepisów, mógł stanowić bardzo użyteczny wzór systematycznego układu prawa ubezpieczeniowego. Gdyby podobnego podziału materii u nas przestrzegano, to po 15 latach prac legislacyjnych stan europeizacji naszego prawa ubezpieczeniowego przedstawiałby się zgola inaczej.

\section{EURO-MERGE OF THE LAW REgARDING INSURANCE CONTRACT}

\section{Summary}

The author presents the origins of the Polish commercial insurance law in the context of the process of its Euro-merge. Special attention is devoted to the evaluation of the quality of the regulation of the insurance contract in the Civil Code against the background of the solutions adopted by laws of particular Western European countries. The above problems are discussed in relation to the freedom of contracts principle, general conditions of insurance, consumer contracts law and the limitations of insurance. The evaluation of the Polish legislation includes interesting remarks de lege ferenda. 